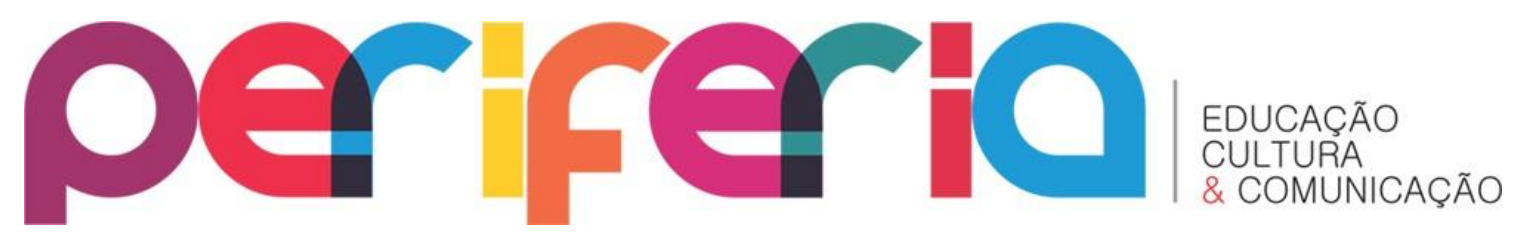

\title{
THE DISABLED POPULATION AND THEIR EDUCATIONAL STATUS IN INDIA
}

\author{
C M Lakshmana ${ }^{1}$ \\ Institute for Social and Economic Change \\ I Maruthi ${ }^{2}$ \\ Institute for Social and Economic Change
}

\section{Abstract}

As per World Health Organisation (WHO) the disabled are deprived of all opportunities for social and economic development. Around 400 million disabled persons live in the developing world. The basic facilities like health, education and employment are denied to this vulnerable section of population. Around 70 per cent of the disabled are unemployed. As per 2011 Census, the total population of India is 1.23 billion, in which about 2.1 per cent (over 21 million people) suffer from one or the other kind of disability. However the present paper focuses the issue of disability and their educational status in India. A state-wise analysis has been done for the study to understand the regional variation. Across the states, the highest number of disabled population is reported from the state of Uttar Pradesh, Maharashtra Andhra Pradesh, Bihar, West Bengal and Madhya Pradesh. Available census data have been used to examine the proportion of disability and their educational status in India for the last two decades. The study found that over a period of time, among disabled persons, not only the educational status of the disabled population has improved during the decade under review, but the percentage of literates among both male and female disabled population has also increased; and their status in higher educational levels has also improved consequently.

Keywords: disabled population; literacy; educational status; higher education; India; decadal overview

\footnotetext{
${ }^{1}$ Doctor of Philosophy (Ph.D.) Geography, Bangalore University, Bangalore. Title of the Thesis: Population Change and Socio-Economic Development of Tumkur District (1998). Master of Arts (M.A.) Geography, Bangalore University, Bangalore. Bachelor of Arts (B.A.), Government Arts College, Bangalore University, Bangalore. Professor \& Head, Population Research Centre, Institute for Social and Economic Change (ISEC), Nagarabhavi, Bengaluru, Karnataka, India560072. Email-lakshmana@isec.ac.in.

${ }^{2} \mathrm{PhD}$ in Sociology- University of Poona, 1994. Title of the Thesis: Social Change Among Holeya Community: A Case Study of Bidar District (K.S.). Associate Professor, ADRTC, ISEC, India. maruthi@isec.ac.in
} 


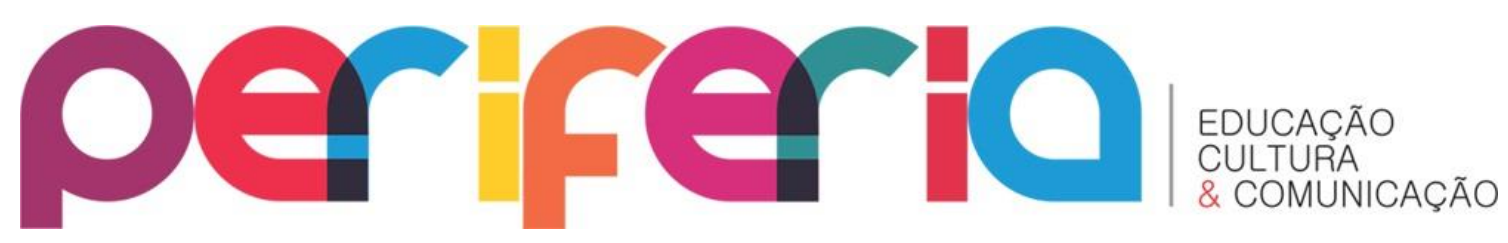

\section{A POPULAÇÃO COM DEFICIÊNCIA E SEU STATUS EDUCACIONAL NA ÍNDIA}

\section{Resumo}

De acordo com a Organização Mundial da Saúde (OMS), os deficientes são privados de todas as oportunidades de desenvolvimento social e econômico. Cerca de 400 milhões de pessoas com deficiência vivem no mundo em desenvolvimento. As instalações básicas, como saúde, educação e emprego são negadas a essa parte vulnerável da população. Cerca de $70 \%$ dos deficientes estão desempregados. De acordo com o Censo de 2011, a população total da Índia é de 1,23 bilhão de habitantes, na qual cerca de 2,1\% (mais de 21 milhões de pessoas) sofrem de um ou outro tipo de deficiência. No entanto, o presente artigo enfoca a questão da deficiência e seu status educacional na Índia. Uma análise de estado-sábio foi feita para o estudo para entender a variação regional. Em todos os estados, o maior número de pessoas com deficiência é relatado em Uttar Pradesh, Maharashtra Andhra Pradesh, Bihar, Bengala Ocidental e Madhya Pradesh. Os dados do censo disponíveis foram usados para examinar a proporção de incapacidade e seu status educacional na Índia nas duas últimas décadas. 0 estudo constatou que, em um período de tempo, entre pessoas com deficiência, não apenas o status educacional da população com deficiência melhorou durante a década em análise, mas também aumentou o percentual de alfabetizados entre a população deficiente feminina e masculina e o seu status, em níveis educacionais mais altos, também melhorou consequentemente.

Palavras-chave: população com deficiência; alfabetização; estado educacional; ensino superior; Índia; visão geral da decada 


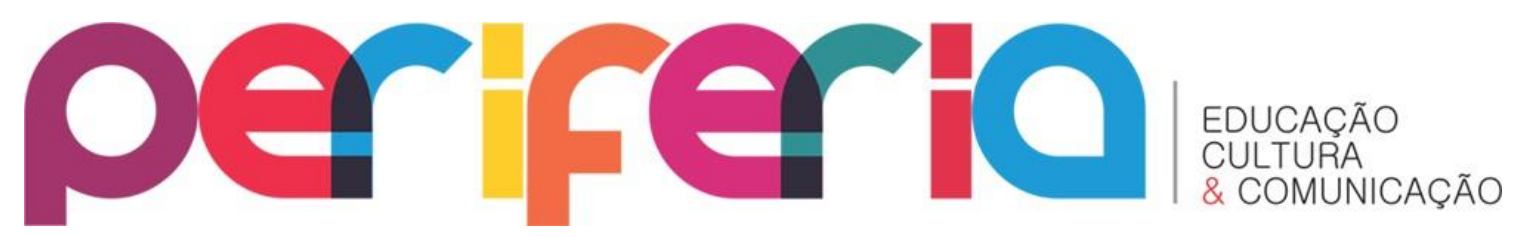

\section{INTRODUCTION}

Disabled people are not only the deprived human beings in the developing world, they also the most neglected (Amartya Sen and James D Wolfensohn, 2014). As revealed by the World Health organisation (WHO), currently around 400 million disabled persons live in the developing world and majority of them are poor. And poverty is the most important cause of their disability. And as per WHO worldwide there are 1.5 million blind children, who are concentrated mainly in Asia and Africa. It is estimated that at least 10 per cent of the developing world's population is disabled in one way or the other. The disabled are deprived of all opportunities for social and economic development. The basic facilities like health, education and employment are denied to this vulnerable section of population. It is estimated that about 40 million of the more than 100 million out of school children have disabilities. Around 70 per cent of the disabled are unemployed. On the other hand, disabled are not a homogeneous group; there are different types of disabilities, with different requirements, and the problems as well as attention and help required by each type are different from the others (Leni Chaudhuri, 2006).

India covers 2.4 per cent of geographical area of the world and 17 per cent of its total population. As per 2011 Census, the total population of India is 1.23 billion, in which about 2.1 per cent (over 21 million people) suffer from one or the other kind of disability. Of the total disabled population males and females are respectively 12.6 and 9.3 millions. Coming to the rural/urban divide, the proportion of disabled is more in rural areas than in urban. This proportion is variously reported as being between 57-58 percent for males and 42-43 percent females. The disability rate per 100,000 populations for the country as whole works out to 2130 . This is 2,369 in the case of males and 1,874 in the case of females. However, there are mainly five types of disabilities found in India, i.e. in seeing, in movement, mental, in speech and in hearing. Among the five types of disabilities on which data has been collected by the Census, disability in seeing at 48.5 per cent incidence has emerged as the top category. Others in sequence are: in movement (27.9 per cent), mental (10.3 


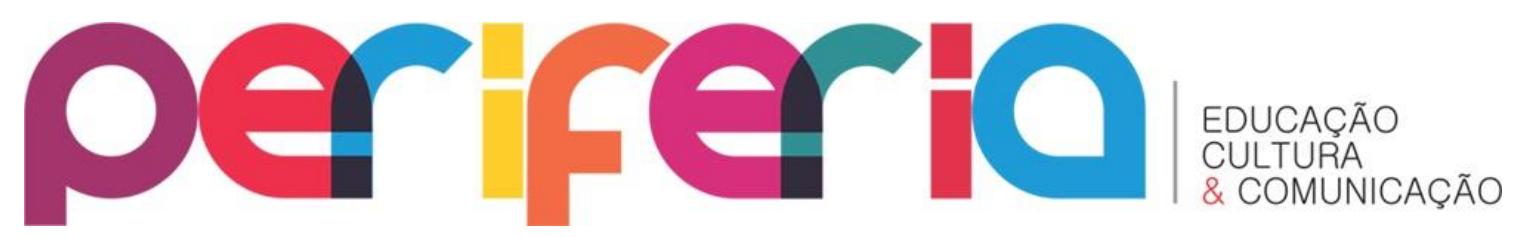

per cent), in speech (7.5 per cent), and in hearing (5.8 per cent). The disabled by sex ratio follow a similar pattern except that the proportion of disabled females is higher in both seeing hearing category.

In view of the above, the main objectives of the paper are to examine the status of disability in India across states for the year 2001 and 2011, and also to understand the educational status among them in India by gender. Data for the study comes from the Census of India; available census data for the year 2001 and 2011 has been used for analysis in the study. The collected data has been classified into various groups and used to make a comparative analysis for the study.

\section{UNDERSTANDING DISABILITY}

Understanding Disability is indeed a difficult task, given it myriad manifestations and intensity. However, according to the World Health Organization (WHO), "Disability is any restriction or lack (resulting from an impairment) of ability to perform in a manner or within the range considered normal for a human being”. Further, persons with Disability Act 1995 defines as a person suffering from not less than forty per cent of any disability as certified by a medical authority as 'disabled'. The National Sample Survey Organisation (NSSO) defines disability as "Any restriction or lack of abilities to perform an activity in the manner or within the range considered normal for human being". It excludes illness /injury of recent origin (morbidity) resulting in temporary loss of ability to see, hear, speak or move.

\section{Types of Disability}

There are mainly six types of disabilities as classified below:

1. Locomotor Disability

2. Visual Disability

3. Mental Illness

4. Speech and Hearing Disability

5. Learning Disability 


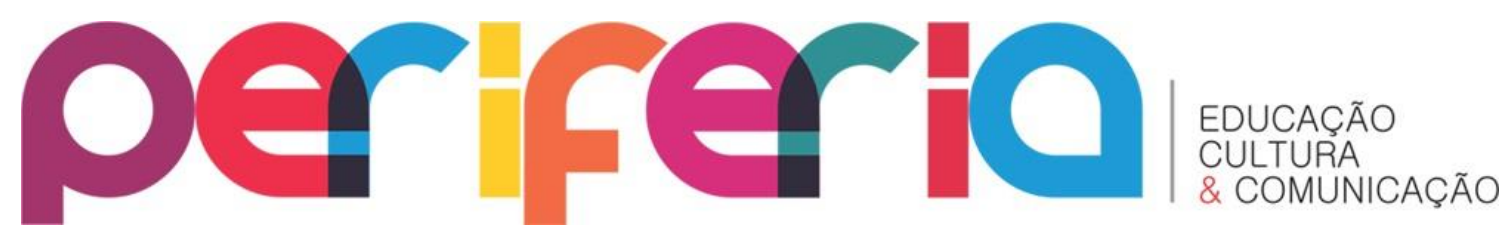

6. Multiple Disability

Given the type and nature of their problem the disabled encounter different types of problems. Some problems are common while others are disability specific.

\section{The Causes of Disability}

According to the World Bank (2012), "Persons with disabilities on average as a group experience worse socio-economic outcomes than persons without disabilities, such as less education, worse health outcomes, less employment, and higher poverty rates. Further, Researchers have demonstrated that these reduced outcomes may be attributed to a myriad of institutional barriers and other factors. Furthermore, the prevalence of disabilities in impoverished populations has been predicted to follow a cyclical pattern by which those who live in poverty are more likely to acquire a disability and those who have a disability are more likely to become impoverished. However, there are several factors lead to Disability.

An expert from the United Kingdom says that Disabled Persons Council attribute the connection between disability and poverty to many systemic factors that promote a "vicious circle (Groce, et al., 2011). And poverty places individuals at a much greater risk of acquiring a disability due to the general lack of health care, nutrition, sanitation, and safe working conditions. Discrimination is another factor that leads to disability. Also, individuals living with disabilities are often impoverished due to the high medical costs associated with their condition. Hence, lack of basic health care is found to be one of the reason for disability in India. Similarly, institutional barriers also play a substantial role in the incidence of poverty in those with disability. Lack of access to education and employment also aggravates the consequences of disability. 


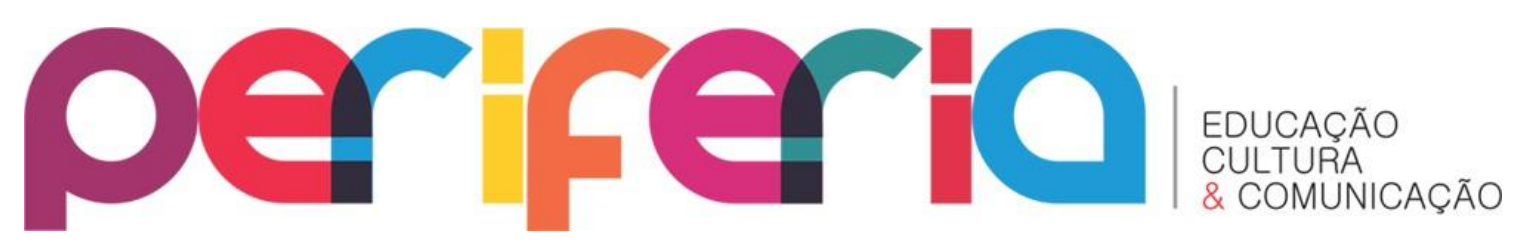

\section{KEY ASPECTS OF DISABLED POPULATION IN INDIA}

Table 1 make clear that as per Census 2001, the total number of disabled population in India was 26.81 million which declined to 21.90 million by 2011 . In regard to the place of residence of the disabled, in the year out of 21.90 million, about 18.63 million were rural residents and 8.17 million were urban residents. 2011 census data shows a marginal decline in the total number of disabled in India as also visible shift in the urban-rural composition of the disabled. For example, 16.38 million disabled are urban residents as per 2011 census as against 18.63 in 2001. Similarly, 5.51 million are urban residents as per 2011 as against 8.17 million in 2001. On the other hand the decline in disability among urban residents urban ( 2.66 million) is slightly higher than that of rural residents ( 2.25 million). A similar decline is apparent among male and female population also. The decline in disability among male population between 2001 and 2011 is 2.38 million; among females it is 2.52 million.

This shows that currently the incidence of male disability is more in males than females in India. However, in absolute numbers, there is higher disability among males, and over a period of time, the decline of disability among males has been lower than among females. Hence, currently, disability is higher among males than females. An in-depth analysis is required to ascertain the root causes of the incidence of higher disability among males in India (Table 1). Proportion of disabled population in India by state for the year 2011 is presented in Fig 1 . This clearly shows that the highest proportion of disabled population is reported from the state of Uttar Pradesh (15.5 per cent), Maharashtra (11.05 per cent), Andhra Pradesh (8.45 per cent), Bihar (8.69 per cent), West Bengal (7.52 per cent), Rajasthan (5.83 per cent), Madhya Pradesh (5.79 per cent), Karnataka (4.94 per cent) Odisha (4.64 per cent) and Tamil Nadu (4.4 per cent). 


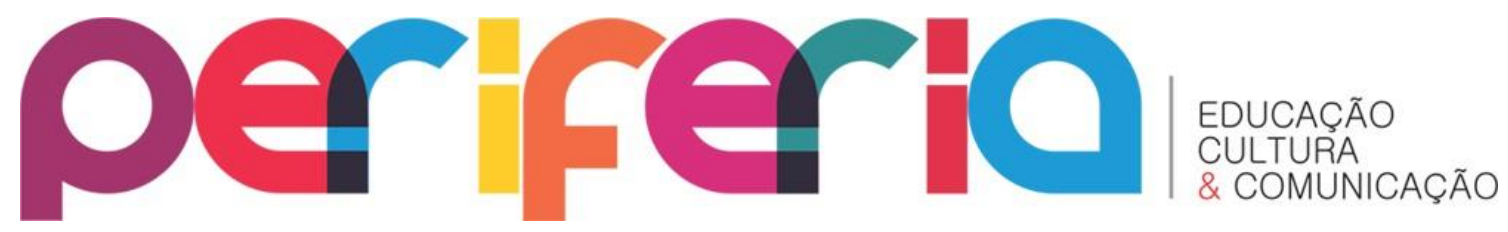

Table 1 - Key Aspects of Disabled Population of India (2001 and 2011)

\begin{tabular}{|c|c|c|c|c|c|c|c|c|c|c|}
\hline & & & \multicolumn{2}{|c|}{ Rural } & \multicolumn{2}{|c|}{ Urban } & \multicolumn{2}{|c|}{ Male } & \multicolumn{2}{|c|}{ Female } \\
\hline & 2001 & 2011 & 2001 & 2011 & 2001 & 2011 & 2001 & 2011 & 2001 & 2011 \\
\hline \multicolumn{11}{|l|}{ Total } \\
\hline \multicolumn{11}{|l|}{ Population } \\
\hline \\
\hline Millions) & 1028 & 1210 & 743 & 833 & 286 & 377 & 532 & 623 & 496 & 586 \\
\hline \multirow{2}{*}{$\begin{array}{l}\text { Disabled } \\
\text { Population }\end{array}$} & & 21.90 & & 16.38 & & 5.51 & & 12.60 & & 9.30 \\
\hline & 26.81 & (4.91) & 18.63 & (2.25) & 8.17 & (2.66) & 14.98 & (2.38) & 11.82 & $(0.78)$ \\
\hline \multicolumn{11}{|l|}{ Per cent of } \\
\hline Disabled & & & & & & & & & & \\
\hline Population & & 1.80 & & 1.96 & & 4.16 & & 1.99 & & 1.58 \\
\hline to the total & 2.60 & $(0.8)$ & 2.50 & $(0.54)$ & 2.85 & $+1.31)$ & 2.81 & $(0.82)$ & 2.38 & $(0.8)$ \\
\hline
\end{tabular}

Source: Census of India (2001 and 2011)

Note: Parenthesis represents the decline/increase of Disability in terms of percentage over 10 years

Figure 1: Percentrage of Disables population in India by State (2011)

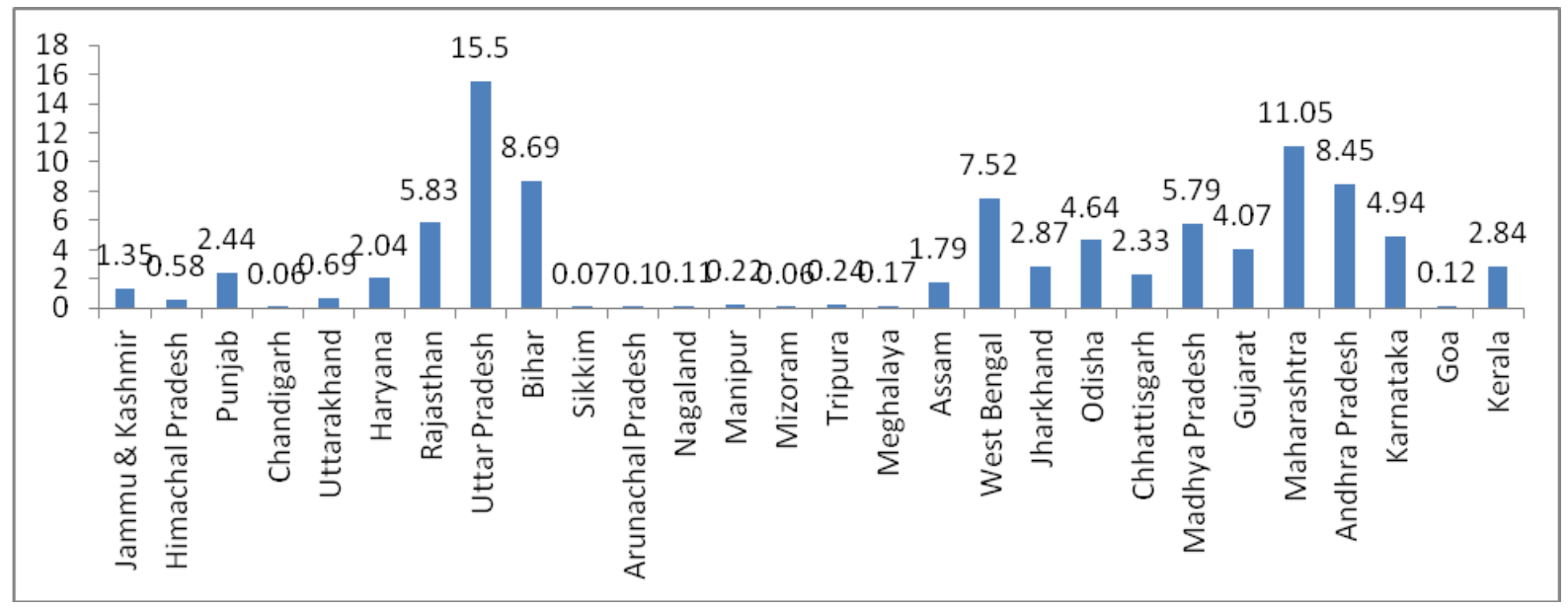

Source: Census of India (2011)

It is clear from the Table 1 that the decline of disability in the total population between 2001 and 2011 is 0.8 in percentage terms. However, it is just 0.54 per cent in case of rural India. Alarmingly, in urban areas there was a gradual increase of disability at 1.31 per cent between 2001 and 2011. The decline of disability across genders was similar during the period studied. 


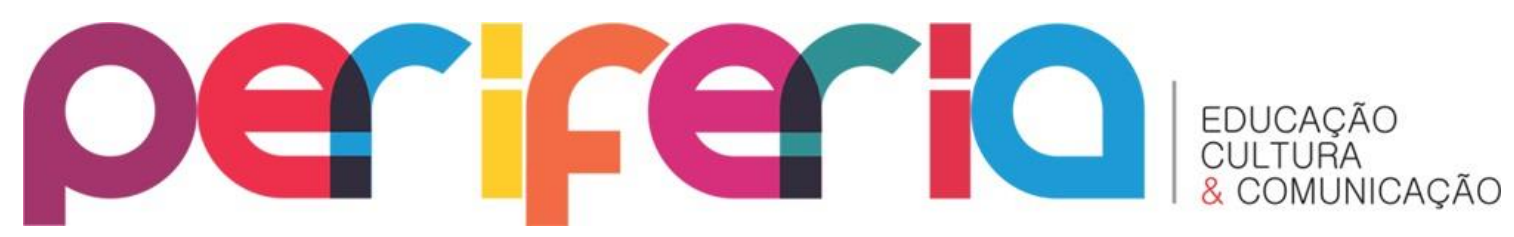

However, increasing poverty in urban areas especially in class 1 and Metropolitan cities is believed to be the main reason for higher incidence of disability in urban areas during the year 2001 and 2011. On the other hand the percent of disabled population in the total in the 2001 was 2.6 per cent, which declined to 1.80 per cent by 2011 . In other words, during the decade 2001 2011, the decline of disability in total population of India was not much, but still over 22 million or 2.1 per cent in the total population, suffer from one or the other form of disability.

\section{PREVALENCE RATE OF DISABILITY IN INDIA BY STATE}

Based on 2011 Census figures, the disability rate (number of disabled per 100,000 populations) for the country as a whole works out to 2130 (2,369 for males and 1,874 for females). Across Indian states, among the five types of disabilities on which data has been collected by the Census, the incidence of locomotors disability is the highest at 48.5 per cent, and occupies the top position. The other disabilities in sequence are: In movement ( 27.9 per cent), Mental (10.3 per cent), In speech (7.5 per cent), and In hearing (5.8 per cent). The disability percentage by gender follows a similar pattern except that the proportion of disabled females is higher in the category 'In seeing and In hearing'.

\section{Prevalence rate among Gender}

According to 2011 figures, Tamil Nadu is the only state where the number of disabled females is higher than disabled males in terms of percentage it is 9.15 per cent and 6.28 per cent respectively for males and females. Compared to the previous census year of 2001, the female disability was higher than male disability in few southern states like Andhra Pradesh (8.81 per cent), Karnataka (5.05 per cent), and Tamil Nadu (4.42 per cent). Female disability was also higher than male disability in the states of Odisha and Rajasthan during that period. Further, female disability increased in the state like West Bengal, 


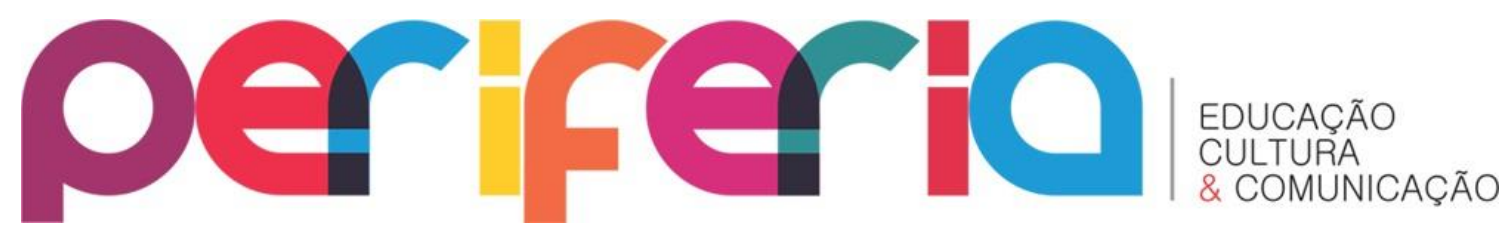

Madhya Pradesh, and Odisha. Between 2001 and 201, interestingly, the state of Karnataka stands as an exception, with significant decline in female disability as per 2011 data. Reasons for this significant decline in female disability in Karnataka as well as those for the increase in disability in states like states of West Bengal, Madhya Pradesh, Odisha and Tamil Nadu needs to be probed in detail in order to chalk out corrective measures. Top ten and bottom ten states with highest and lowest share of disabled population by gender for the year 2001 and 2011 is presented in Table 2 a, b and 3 a and b. As can be seen from the table, there is not much difference between males and females in the incidence of disability in the above states, except that in the rest of the states, disability is comparatively high among males. However over a period of time there is a gradual decline of female disability across states in the county.

Table 2 a: Top 10 States with High Percentage of Disabled Population in India (2001)

\begin{tabular}{|c|l|c|c|}
\hline \multirow{2}{*}{ Sl.No. } & \multicolumn{1}{|c|}{ State } & \multicolumn{2}{c|}{ Percentage of Population (2001) } \\
\cline { 3 - 4 } & & Male & Female \\
\hline 1 & Uttar Pradesh & 15.77 & 15.16 \\
\hline 2 & Maharashtra & 11.29 & 10.75 \\
\hline 3 & Bihar & 8.96 & 8.35 \\
\hline 4 & Andhra Pradesh & 8.17 & 8.81 \\
\hline 5 & West Bengal & 7.52 & 7.53 \\
\hline 6 & Madhya Pradesh & 5.93 & 5.61 \\
\hline 7 & Rajasthan & 5.66 & 6.05 \\
\hline 8 & Karnataka & 4.85 & 5.05 \\
\hline 9 & Odisha & 4.50 & 4.82 \\
\hline 10 & Tamil Nadu & 4.39 & 4.42 \\
\hline
\end{tabular}




\section{per ferio

Table 2 b: Top 10 States with High Percentage of Disabled Population in India (2011)

\begin{tabular}{|c|l|c|c|}
\hline \multirow{2}{*}{ SI.No. } & \multirow{2}{*}{ State } & \multicolumn{2}{|c|}{ Percentage of Population (2011) } \\
\cline { 3 - 4 } & Male & Female \\
\hline 1 & Uttar Pradesh & 16.47 & 14.80 \\
\hline 2 & Bihar & 8.98 & 8.13 \\
\hline 3 & West Bengal & 8.40 & 8.48 \\
\hline 4 & Maharashtra & 7.41 & 6.83 \\
\hline 5 & Rajasthan & 6.67 & 6.14 \\
\hline 6 & Madhya Pradesh & 6.54 & 6.28 \\
\hline 7 & Tamil Nadu & 6.28 & 9.15 \\
\hline 8 & Andhra Pradesh & 6.14 & 6.35 \\
\hline 9 & Gujarat & 4.80 & 4.74 \\
\hline 10 & Odisha & 4.51 & 4.86 \\
\hline
\end{tabular}

Table 3 a: Bottom 10 States with Low Percentage of Disabled Population in India (2001)

\begin{tabular}{|c|l|c|c|}
\hline \multirow{2}{*}{ SI.No. } & \multirow{2}{*}{ State } & \multicolumn{2}{|c|}{ Percentage of Population (2001) } \\
\cline { 3 - 4 } & Mizoram & 0.05 & Female \\
\hline 1 & Chandigarh & 0.06 & 0.06 \\
\hline 2 & Sikkim & 0.07 & 0.05 \\
\hline 3 & Arunachal Pradesh & 0.10 & 0.07 \\
\hline 4 & Nagaland & 0.11 & 0.11 \\
\hline 5 & 0.11 & 0.11 \\
\hline 6 & Goa & 0.16 & 0.14 \\
\hline 7 & Meghalaya & 0.21 & 0.18 \\
\hline 8 & Manipur & 0.24 & 0.23 \\
\hline 9 & Tripura & 0.58 & 0.24 \\
\hline 10 & Himachal Pradesh & & 0.58 \\
\hline
\end{tabular}

Table 3 b: Bottom 10 States with Low Percentage of Disabled Population in India (2011)

\begin{tabular}{|c|l|c|c|}
\hline \multirow{2}{*}{ SI.No. } & \multirow{2}{*}{ State } & \multicolumn{2}{c|}{ Percentage of Population (2011) } \\
\cline { 3 - 4 } & Male & Female \\
\hline 1 & Mizoram & 0.07 & 0.08 \\
\hline 2 & Goa & 0.07 & 0.07 \\
\hline 3 & Chandigarh & 0.08 & 0.06 \\
\hline 4 & Sikkim & 0.09 & 0.10 \\
\hline 5 & Nagaland & 0.12 & 0.13 \\
\hline 6 & Meghalaya & 0.12 & 0.14 \\
\hline 7 & Manipur & 0.12 & 0.14 \\
\hline 8 & Arunachal Pradesh & 0.18 & 0.12 \\
\hline 9 & Tripura & 0.27 & 0.27 \\
\hline 10 & Himachal Pradesh & 0.72 & 0.70 \\
\hline
\end{tabular}

Source: Classified by the Author using Census Data 


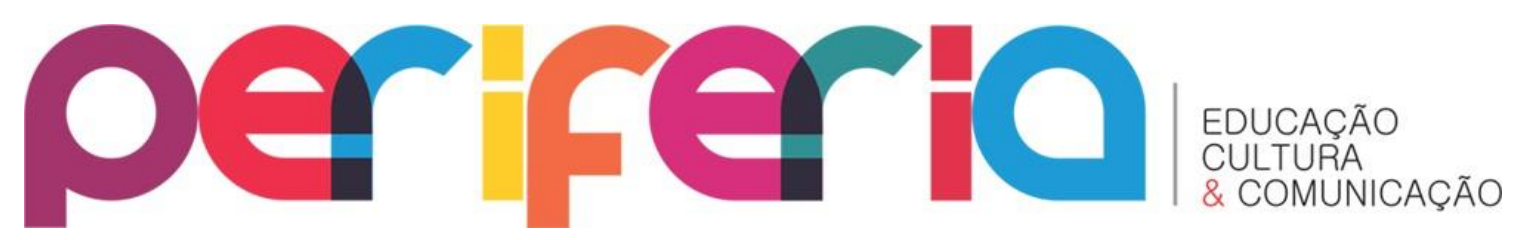

Prevalence rate by Rural and Urban

The incidence of disability (in percentage terms) across rural and urban areas for the year 2001 is shown in Table $4 \mathrm{a}$. It is clear that, the top ten states with the highest rural disability areas are Uttar Pradesh (16.51 per cent), Bihar (10.98 per cent), Maharashtra (8.94 per cent), Andhra Pradesh (8.12 per cent), West Bengal (7.35 per cent), followed by Rajasthan (6.54 per cent), Madhya Pradesh (5.93 per cent), Odisha (5.73 per cent), Karnataka (4.25 per cent) and Tamil Nadu (3.34 per cent). A close look at the figures of disability across top ten states for the next year of 2011 shows that the progressive state of Karnataka does not find a place among the top ten states (Table 4 b). Further, in regard to the prevalence of disability in rural areas across top ten states between 2001 and 2011, it is seen that that the increase in disability in percentage terms was high in the states of West Bengal, Tamil Nadu, Rajasthan, and Madhya Pradesh, while the remaining states like Uttar Pradesh, Bihar, Andhra Pradesh and Odisha had shown considerable decline.

Coming to the urban scenario in this regard, in the year 2011 the states of Uttar Pradesh, Tamil Nadu, Maharashtra, West Bengal, Gujarat, Madhya Pradesh and Andhra Pradesh had the highest proportion of disabled population in their urban parts. However, as compared to the previous census year, there were significant changes in disability figures in the top ten states. For example, the percentage of disabled population in Tamil Nadu and Maharashtra, increased by almost 5 and 6 per cent respectively (see Tables 4 a and b). In the reaming states like Uttar Pradesh, Bihar, West Bengal, Rajasthan and Madhya Pradesh, the shift in percentage of disability between male/female and urban/rural has been marginal. . Further, there was not much difference in the percentage of disability in Odisha between 2001 and 2011in al the above categories. (Please refer Table $5 \mathrm{a}$, and $\mathrm{b}$ for bottom ten states with regard to percentage of disabled population for the year 2001 and 2011.) 


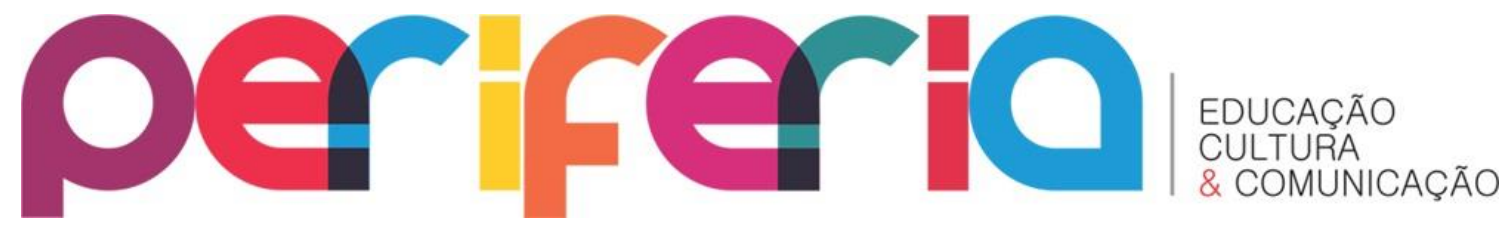

Table 4.a: Top 10 States with High Percentage of Disabled Population in India (2001)

\begin{tabular}{|c|l|c|c|c|}
\hline \multirow{2}{*}{ SI.No. } & \multirow{2}{*}{ State } & \multicolumn{3}{|c|}{ Percentage of Population (2001) } \\
\cline { 3 - 5 } & Uttar Pradesh & 15.76 & Rural & Urban \\
\hline 1 & Uttar & 16.51 & 13.55 \\
\hline 2 & Bihar & 8.62 & 10.33 & 3.54 \\
\hline 3 & West Bengal & 8.43 & 8.26 & 8.93 \\
\hline 4 & Tamil Nadu & 7.5 & 5.77 & 12.64 \\
\hline 5 & Maharashtra & 7.16 & 6.23 & 9.95 \\
\hline 6 & Rajasthan & 6.45 & 6.77 & 5.48 \\
\hline 7 & Madhya Pradesh & 6.43 & 6.47 & 6.31 \\
\hline 8 & Andhra Pradesh & 6.23 & 6.41 & 5.7 \\
\hline 9 & Gujarat & 4.77 & 4.39 & 5.91 \\
\hline 10 & Odisha & 4.66 & 5.36 & 2.6 \\
& & & & \\
\hline
\end{tabular}

Table 4.b: Top 10 States with High Percentage of Disabled Population in India (2011)

\begin{tabular}{|c|l|c|c|c|}
\hline \multirow{2}{*}{$\begin{array}{l}\text { SI } \\
\text { No. }\end{array}$} & \multicolumn{1}{|c|}{ State } & \multicolumn{3}{|c|}{ Percentage of Population (2011) } \\
\cline { 3 - 5 } & Total & Rural & Urban \\
\hline 1 & Uttar Pradesh & 15.5 & 16.99 & 12.12 \\
\hline 2 & Maharashtra & 11.05 & 8.94 & 15.86 \\
\hline 3 & Bihar & 8.69 & 10.98 & 3.48 \\
\hline 4 & Andhra Pradesh & 8.45 & 8.12 & 9.21 \\
\hline 5 & West Bengal & 7.52 & 7.35 & 7.93 \\
\hline 6 & Rajasthan & 5.83 & 6.54 & 4.21 \\
\hline 7 & Madhya Pradesh & 5.79 & 5.93 & 5.46 \\
\hline 8 & Karnataka & 4.94 & 4.25 & 6.5 \\
\hline 9 & Odisha & 4.64 & 5.73 & 2.16 \\
\hline 10 & Tamil Nadu & 4.4 & 3.34 & 6.83 \\
\hline
\end{tabular}




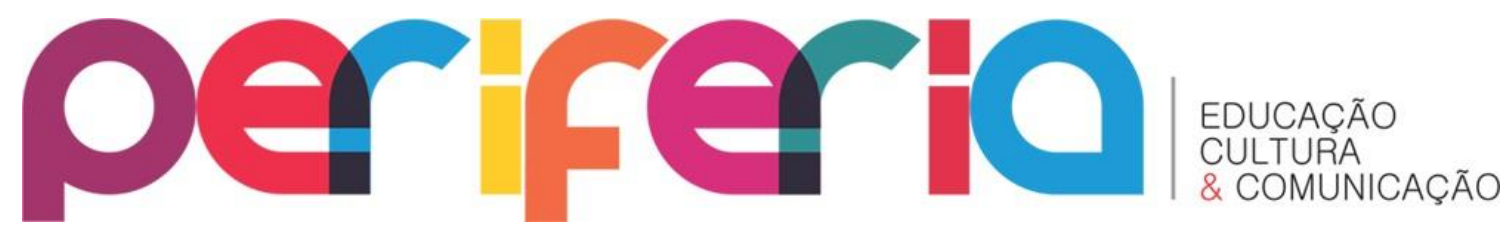

Table 5 a: Bottom 10 States with low Percentage of Disabled Population in India (2001)

\begin{tabular}{|c|l|c|c|c|}
\hline \multirow{2}{*}{ SI.No. } & \multirow{2}{*}{ State } & \multicolumn{3}{|c|}{ Percentage of Population (2001) } \\
\cline { 2 - 5 } & Total & Rural & Urban \\
\hline 1 & Chandigarh & 0.07 & 0.01 & 0.25 \\
\hline 2 & Mizoram & 0.07 & 0.06 & 0.11 \\
\hline 3 & Goa & 0.07 & 0.05 & 0.13 \\
\hline 4 & Sikkim & 0.09 & 0.11 & 0.03 \\
\hline 5 & Nagaland & 0.12 & 0.14 & 0.05 \\
\hline 6 & Manipur & 0.13 & 0.13 & 0.13 \\
\hline 7 & Meghalaya & 0.13 & 0.14 & 0.11 \\
\hline & Arunachal & & & \\
8 & Pradesh & 0.15 & 0.17 & 0.11 \\
\hline 9 & Tripura & 0.27 & 0.3 & 0.18 \\
\hline 10 & Himachal Pradesh & 0.71 & 0.88 & 0.2 \\
\hline
\end{tabular}

Table 5 b: Bottom 10 States with low Percentage of Disabled Population in India (2011)

\begin{tabular}{|c|l|c|c|c|}
\hline \multirow{2}{*}{$\begin{array}{l}\text { Sl } \\
\text { No. }\end{array}$} & \multicolumn{1}{|c|}{ State } & \multicolumn{3}{|c|}{ Percentage of Population (2011) } \\
\cline { 2 - 5 } & Total & Rural & Urban \\
\hline 1 & Mizoram & 0.06 & 0.05 & 0.08 \\
\hline 2 & Chandigarh & 0.06 & 0 & 0.18 \\
\hline 3 & Sikkim & 0.07 & 0.09 & 0.03 \\
\hline 4 & Arunachal Pradesh & 0.1 & 0.12 & 0.05 \\
\hline 5 & Nagaland & 0.11 & 0.13 & 0.22 \\
\hline 6 & Goa & 0.12 & 0.08 & 0.22 \\
\hline 7 & Meghalaya & 0.17 & 0.2 & 0.08 \\
\hline 8 & Manipur & 0.22 & 0.22 & 0.22 \\
\hline 9 & Tripura & 0.24 & 0.24 & 0.24 \\
\hline 10 & Himachal Pradesh & 0.58 & 0.77 & 0.15 \\
\hline
\end{tabular}

Source: Classified by the Author using Census Data

\section{GROWTH OF DISABLED POPULATION IN INDIA BY STATE}

The data on disabled population in India by State and residence is presented in Table 6. In the decade 2001-2011, the States like Goa, Maharshtra the north- eastern state of Manipur, Jharkhand and the state of Andhra Pradesh witnessed the highest growth of population, i.e. increase of 109.61 per cent, 88.80 per cent, 106.33 per cent, 71.73 per cent and 66.05 per cent respectively. Further, these states had also witnessed the highest growth 


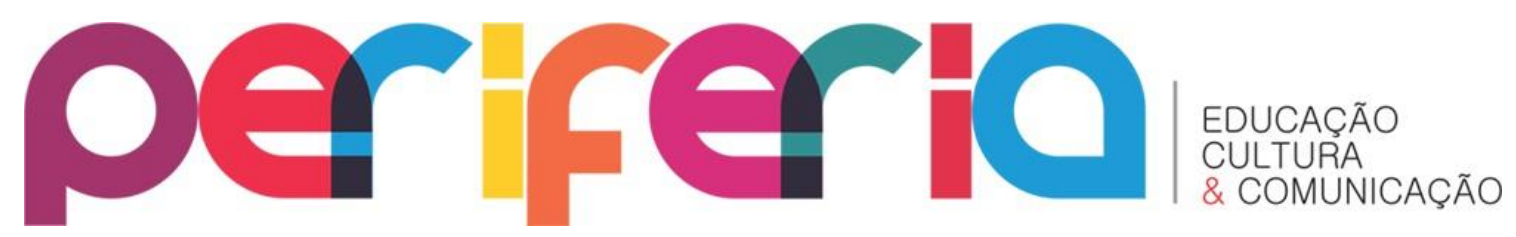

in both rural and urban population. While the states of Himachal Pradesh, Chandigarh, Uttarakhand, Sikkim Arunachal Pradesh, Mizoram, Assam, Kerala and Tamil Nadu registered negative or nil growth rate in disabled population, the rest of the states saw positive growth in the number of disabled population during the decade 2001-2011. Coming to the growth rate of rural disabled population, it is seen that the states of Himachal Pradesh, Uttarkhand, Sikkim, Arunachal Pradesh, Mizoram, Tripura, Assam, Gujarat, Kerala and Tamil Nadu witnessed negative growth of population, while all states excepting the states of Arunachal Pradesh and Tamil Nadu, registered positive growth in the number of urban disabled during the decade. It indicates that incidence of disability has been more in urban areas than rural.

\section{EDUCATIONAL STATUS OF DISABLED POPULATION IN INDIA}

As regards the educational level of the disabled population, as of 2011 out of the 26.8 million disabled in India, about 14.6 million (54.5 per cent) are literates and the remaining 12.2 million (45.5 per cent) illiterates(Table 7). However, over the years, there has been considerable improvement in educational status of disabled population in the country. This is true for both males and females, but also there is significant improvement in their educational attainment in general and higher education in particular. For instance, as per 2001 Census Graduate and above qualification among males is 6.6 per cent which increased to almost 9 per cent by 2011. Similar improvement is seen for females also (4.6 per cent in 2001 and 7.7 per cent in 2011). Overall literacy level of the disabled in India has increased over time, i.e. from 50.7 per cent (2001) to 55.4 per cent (2011). Hence, the main objective of the paper is to make a detailed analysis of available data with a view to understanding the extent of disability by residence and sex on the one hand, and their educational status in comparative terms for the last two decades in India by state on the other.

A comparison in terms of literacy status, educational level among literates and gender of the disabled population in India between the years 2001 


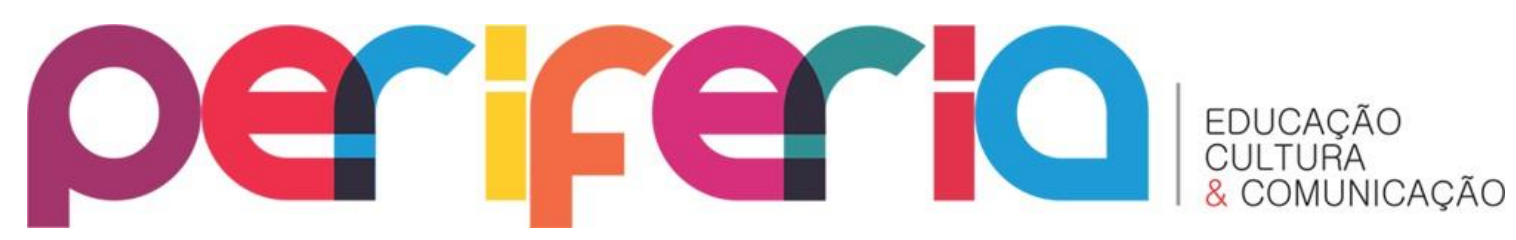

and 2011 is presented in Table 6. The total number of disabled population in India as per 2011 census is 26.8 million, in which 14.6 million are literates and the remaining 12.2 million are illiterates. In percentage terms, it roughly amounts to 54.5 per cent and 45.5 per cent respectively. As of 2001 , the percentage of literates in the disabled population was 49.3 per cent which increased to 54.5 per cent in 2011. However, the latest decade saw a considerable increase (5.2 percent) in the number of literates among disabled population in India. Interestingly, the percentage increase in the number of female literates between 2001 and 2011 was higher than male literates, the percentage increase being 4.3 per cent and 7.3 per cent respectively for males and females (Table 7).

Here, it is important to note that in the decade 2001-2011, there was not only a significant increase in the percentage of literates among both male and female the disabled population, but their status in higher educational levels has also shown considerable improvement. For instance, on the one hand, over the years under study, the numbers of disabled with below primary level education declined by 7.1 per cent; similarly the percentage of disabled population with primary but below middle level of schooling which deceased to 2.1 per cent. On the other, the decade also witnessed a considerable increase in the percentage of disabled with metric/secondary but below graduate level education by 3.4 per cent and an above 2.5 per cent increase in the number of disabled persons with Graduate and above level education.

It is worth noting that in 2011 , the percentage of disabled females with higher education (metric/secondary but below graduate) was 4.3 percent and that of disabled males 3.1percent, as against 3.4 per cent and 2.4 per cent respectively in 2001. 


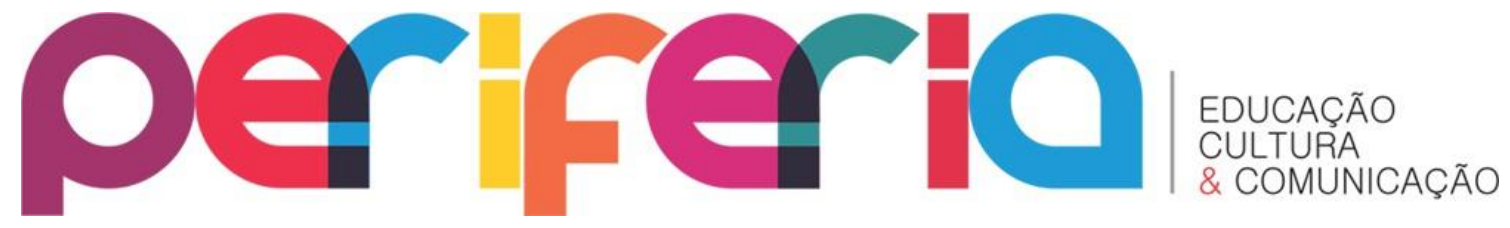

Table 6: Growth rate of Disabled Population in India By states (2011)

\begin{tabular}{|c|c|c|c|c|c|c|c|}
\hline \multirow[b]{2}{*}{ Sl.no } & \multicolumn{4}{|c|}{ Disabled Population in India by States-2011 } & \multirow{2}{*}{$\begin{array}{c}\text { Total } \\
\text { Growth } \\
\text { rate in } \\
\% \\
(2011)\end{array}$} & \multirow{2}{*}{$\begin{array}{c}\text { Rural } \\
\text { Growth } \\
\text { rate in } \\
\% \\
(2011)\end{array}$} & \multirow{2}{*}{$\begin{array}{c}\text { Urban } \\
\text { Growth } \\
\text { rate in } \\
\% \\
(2011)\end{array}$} \\
\hline & States & Total & Rural & Urban & & & \\
\hline 1 & $\begin{array}{l}\text { Jammu \& } \\
\text { Kashmir }\end{array}$ & 361153 & 273952 & 87201 & 19.32 & 19.26 & 19.53 \\
\hline 2 & $\begin{array}{l}\text { Himachal } \\
\text { Pradesh }\end{array}$ & 155316 & 142665 & 12651 & -0.41 & -1.44 & 13.02 \\
\hline 3 & Punjab & 654063 & 430313 & 223750 & 54.07 & 44.88 & 75.48 \\
\hline 4 & Chandigarh & 14796 & 346 & 14450 & -4.78 & -79.11 & 4.09 \\
\hline 5 & Uttarakhand & 185272 & 134097 & 51175 & -4.88 & -13.39 & 28.13 \\
\hline 6 & Haryana & 546374 & 357663 & 188711 & 20.07 & 5.26 & 63.74 \\
\hline 7 & Rajasthan & 1563694 & 1219186 & 344508 & 10.74 & 9.90 & 13.85 \\
\hline 8 & $\begin{array}{l}\text { Uttar } \\
\text { Pradesh }\end{array}$ & 4157514 & 3166615 & 990899 & 20.39 & 17.03 & 32.55 \\
\hline 9 & Bihar & 2331009 & 2046351 & 284658 & 23.49 & 20.91 & 45.86 \\
\hline 10 & Sikkim & 18187 & 15859 & 2328 & -10.70 & -14.60 & 29.62 \\
\hline 11 & $\begin{array}{l}\text { Arunachal } \\
\text { Pradesh }\end{array}$ & 26734 & 22308 & 4426 & -19.75 & -18.75 & -24.46 \\
\hline 12 & Nagaland & 29631 & 23549 & 6082 & 11.82 & 0.12 & 104.16 \\
\hline 13 & Manipur & 58547 & 40488 & 18059 & 106.33 & 93.21 & 143.35 \\
\hline 14 & Mizoram & 15160 & 8627 & 6533 & -5.32 & -10.98 & 3.37 \\
\hline 15 & Tripura & 64346 & 44942 & 19404 & 9.17 & -7.91 & 91.36 \\
\hline 16 & Meghalaya & 44317 & 37566 & 6751 & 53.86 & 65.20 & 11.35 \\
\hline 17 & Assam & 480065 & 415457 & 64608 & -9.47 & -11.25 & 3.89 \\
\hline 18 & West Bengal & 2017406 & 1368942 & 648464 & 9.22 & 1.08 & 31.56 \\
\hline 19 & Jharkhand & 769980 & 597544 & 172436 & 71.73 & 71.25 & 73.39 \\
\hline 20 & Odisha & 1244402 & 1067739 & 176663 & 21.84 & 21.65 & 23.00 \\
\hline 21 & Chhattisgarh & 624937 & 498228 & 126709 & 48.83 & 44.42 & 69.18 \\
\hline 22 & $\begin{array}{l}\text { Madhya } \\
\text { Pradesh }\end{array}$ & 1551931 & 1105704 & 446227 & 10.18 & 4.27 & 28.19 \\
\hline 23 & Gujarat & 1092302 & 570479 & 521823 & 4.48 & -20.70 & 60.02 \\
\hline 24 & Maharashtra & 2963392 & 1666135 & 1297257 & 88.80 & 63.29 & 136.20 \\
\hline 25 & $\begin{array}{l}\text { Andhra } \\
\text { Pradesh }\end{array}$ & 2266607 & 1512961 & 753646 & 66.05 & 44.04 & 139.57 \\
\hline 26 & Karnataka & 1324205 & 792694 & 531511 & 40.78 & 19.90 & 90.16 \\
\hline 27 & Goa & 33012 & 14622 & 18390 & 109.61 & 70.84 & 155.77 \\
\hline 28 & Kerala & 761843 & 414875 & 346968 & -11.50 & -35.95 & 62.89 \\
\hline 29 & Tamil Nadu & 1179963 & 621745 & 558218 & -28.16 & -34.21 & -19.97 \\
\hline 30 & India & $26,814,994$ & $18,636,358$ & $8,178,636$ & & & \\
\hline
\end{tabular}

Source: Classified by the Author using Census Data

\section{Educational Level among Disabled Population: Inter-State variation}

In order to understand the level of education of the disabled population in India by states, the states are slotted into three groups, i.e. (i) top ten (ii) 


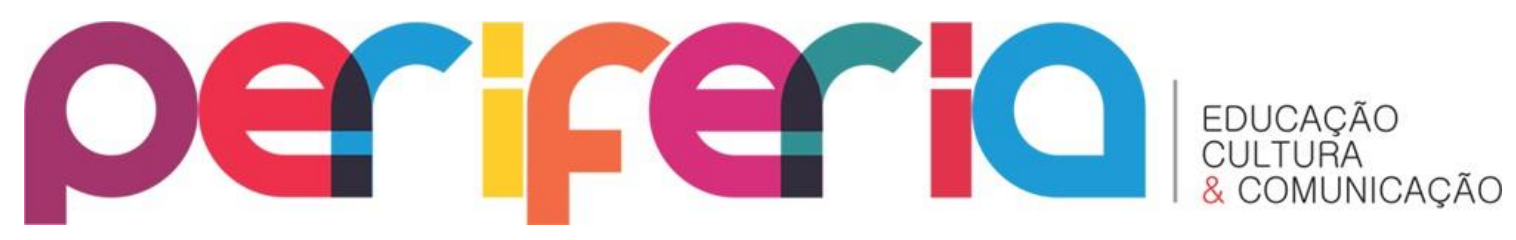

bottom ten and (iii) those in the middle. The education level of the total disabled population within each of the states is arranged in percentages and provided in Table 8. However, the education level of disabled people varies widely across Indian states. For instance, if the level of primary education among the top ten states is taken, it can be seen that the northern state of Mizoram has the highest percentage of disabled population in its total population.

However, if attainment of below middle level education by the disabled in the top top ten states is considered, the eastern state of Odisha has the highest percentage of those with below middle education level. If the percentage of disabled who have completed below matric/secondary level is considered, the state of Jammu and Kashmir is at the top position.. Interestingly the highest proportion of persons who have completed secondary but below graduate and Graduate and above are found in the progressive state of Punjab followed by the union territory of Chandigarh. (Please refer to Table 8 to understand the educational level below primary in bottom ten states.)

In regard to the percentage of disabled literates with Educational level below middle school in the states, it seen that large number of persons numbers under this category are concentrated in the top ten states, with Odisha having the highest percentage at 31.88 , followed by Rajasthan (30.35 per cent), Himachal Pradesh (30.02 per cent), Madhya Pradesh (29.27 per cent), Jharkhand (28.98 per cent), Nagaland (28.78 per cent), Chhattisgarh, Bihar and Tamil Nadu (all 27\% each). The six north-eastern states, Goa, Chandigarh, Jammu \& Kashmir and the western state of Maharashtra are the bottom ten states with regard to educational level below middle school category.

The state of Jammu \& Kashmir has the highest percentage (26.58) of disabled educated persons under below metric/secondary category, followed in Manipur (25.56 per cent), Uttar Pradesh (22 per cent), Assam (21.87 per cent), Nagaland (21.63 per cent), and Uttarakhand (21.59 per cent). Among the top ten states Madhya Pradesh, Rajasthan and Chhattisgarh have over 21 percent disabled persons with below metric/secondary level category. Table 8 


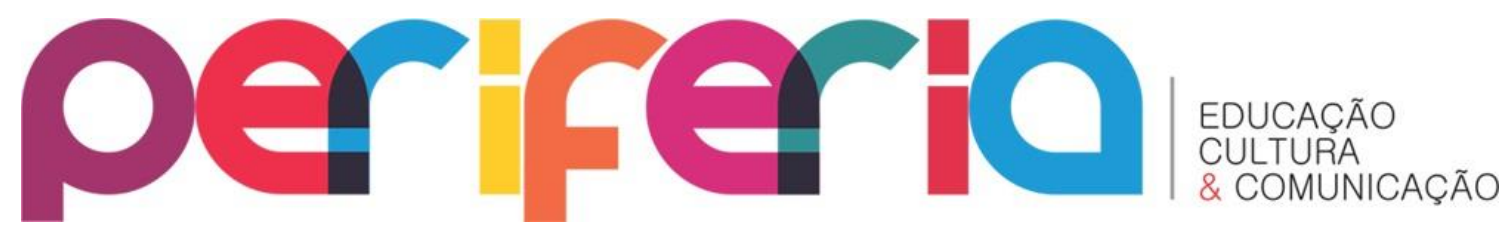

lists the bottom-ten states under this categorisation; the rest of the states come under the middle category of having educational level below metric/secondary.

A look at the education level of the disabled (attainment of secondary education level), reveals that the states of Punjab, Goa, UT of Chandigarh, Karnataka, Andhra Pradesh, Manipur, Jammu \& Kashmir, Tamil Nadu, Himachal Pradesh and Haryana have the highest percentage of disabled population who have completed secondary education. The lowest percentage observed is in Haryana (30.54 per cent) and maximum percentage observed in

Table 7: Percentage distribution of Disabled Population by Literacy status and Educational level in India (2001 and 2011)

\begin{tabular}{|c|c|c|c|c|c|c|c|c|c|}
\hline \multirow{2}{*}{$\begin{array}{l}\text { Literacy status } \\
\text { and Educational } \\
\text { Level among } \\
\text { disabled } \\
\text { population }\end{array}$} & \multicolumn{3}{|c|}{2001} & \multicolumn{3}{|c|}{2011} & \multicolumn{3}{|c|}{$\begin{array}{l}\text { Progress between } \\
2001 \& 2011\end{array}$} \\
\hline & Total & Male & Female & Total & Male & Female & Total & Male & Female \\
\hline Illiterate & 50.7 & 41.9 & 62.7 & 45.5 & 37.6 & 55.4 & -5.2 & -4.3 & -7.3 \\
\hline Literate & 49.3 & 58.1 & 37.3 & 54.5 & 62.4 & 44.6 & 5.2 & 4.3 & 7.3 \\
\hline $\begin{array}{l}\text { Percentage to } \\
\text { Literates }\end{array}$ & & & & & & & 0 & 0 & 0 \\
\hline $\begin{array}{l}\text { Literate but } \\
\text { below primary }\end{array}$ & 26.5 & 25 & 29.9 & 19.4 & 18.5 & 21.5 & -7.1 & -6.5 & -8.4 \\
\hline $\begin{array}{l}\text { Primary but } \\
\text { below middle }\end{array}$ & 26.4 & 25.6 & 28.1 & 24.3 & 23.5 & 25.8 & -2.1 & -2.1 & -2.3 \\
\hline $\begin{array}{l}\text { Middle but below } \\
\text { matric.secondary }\end{array}$ & 16.4 & 16.6 & 14.8 & 16.7 & 17.3 & 15.8 & 0.3 & 0.7 & 1 \\
\hline $\begin{array}{l}\text { Matric/Secondary } \\
\text { but below } \\
\text { graduate }\end{array}$ & 20 & 21.5 & 16.9 & 23.6 & 24.9 & 21.2 & 3.6 & 3.4 & 4.3 \\
\hline $\begin{array}{l}\text { Graduate and } \\
\text { above }\end{array}$ & 6 & 6.6 & 4.6 & 8.5 & 9 & 7.7 & 2.5 & 2.4 & 3.1 \\
\hline
\end{tabular}

Source: Registrar General of India, Ministry of Home Affairs, Govt. Of India. July 2016

Table 8: Educational status of Disabled population in India (2001 and 2011)

\begin{tabular}{|l|l|l|l|l|l|l|l|l|}
\hline \multicolumn{3}{|c|}{ Below primary } & \multicolumn{4}{c|}{ Below middle } & \multicolumn{3}{c|}{ Below metric/secondary } \\
\hline $\begin{array}{l}\text { Sl. } \\
\text { No. }\end{array}$ & $\begin{array}{l}\text { Top Ten } \\
\text { States }\end{array}$ & Percentage & $\begin{array}{l}\text { Sl. } \\
\text { No. }\end{array}$ & $\begin{array}{l}\text { Top Ten } \\
\text { States }\end{array}$ & Percentage & $\begin{array}{l}\text { Sl. } \\
\text { No. }\end{array}$ & $\begin{array}{l}\text { Top Ten } \\
\text { States }\end{array}$ & Percentage \\
\hline 1 & Mizoram & 43.87 & 1 & Odisha & 31.88 & 1 & $\begin{array}{l}\text { Jammu \& } \\
\text { Kashmir }\end{array}$ & 26.58 \\
\hline 2 & Meghalaya & 39.53 & 2 & Rajasthan & 30.35 & 2 & Manipur & 25.56 \\
\hline 3 & Sikkim & 36.31 & 3 & $\begin{array}{l}\text { Himachal } \\
\text { Pradesh }\end{array}$ & 30.02 & 3 & Uttar Pradesh & 22.01 \\
\hline 4 & Tripura & 30.75 & 4 & $\begin{array}{l}\text { Andhra } \\
\text { Pradesh }\end{array}$ & 29.59 & 4 & Assam & 21.87 \\
\hline
\end{tabular}




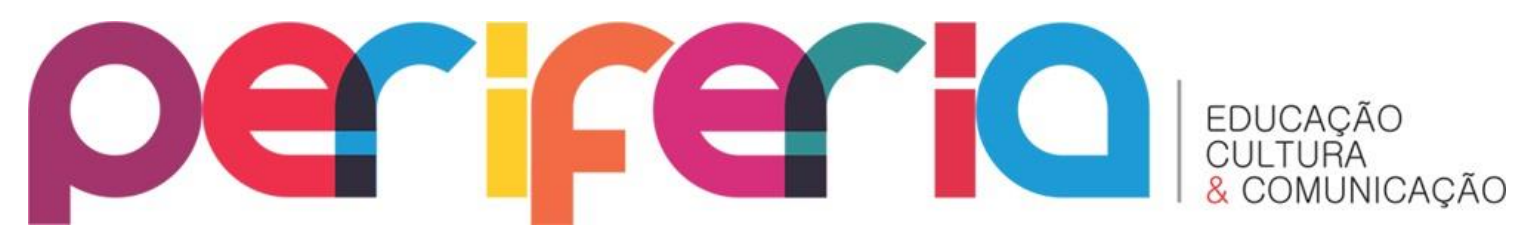

\begin{tabular}{|c|c|c|c|c|c|c|c|c|}
\hline 5 & West Bengal & 29.57 & 5 & $\begin{array}{l}\text { Madhya } \\
\text { Pradesh }\end{array}$ & 29.27 & 5 & Nagaland & 21.63 \\
\hline 6 & Assam & 28.55 & 6 & Jharkhand & 28.98 & 6 & Uttarakhand & 21.59 \\
\hline 7 & Chhattisgarh & 27.85 & 7 & Nagaland & 28.78 & 7 & Tripura & 20.95 \\
\hline 8 & Odisha & 27.23 & 8 & Chhattisgarh & 27.57 & 8 & $\begin{array}{l}\text { Madhya } \\
\text { Pradesh }\end{array}$ & 20.55 \\
\hline 9 & Nagaland & 25.95 & 9 & Bihar & 27.11 & 9 & Rajasthan & 20.48 \\
\hline 10 & Kerala & 24.76 & 10 & & 27.11 & 10 & Chhattisgarh & 20.31 \\
\hline \multicolumn{3}{|c|}{ Bottom Ten States } & \multicolumn{3}{|c|}{ Bottom Ten States } & \multicolumn{3}{|c|}{ Bottom Ten States } \\
\hline 1 & $\begin{array}{l}\text { Uttar } \\
\text { Pradesh }\end{array}$ & 17.10 & 1 & Meghalaya & 25.05 & 1 & $\begin{array}{l}\text { Himachal } \\
\text { Pradesh }\end{array}$ & 17.11 \\
\hline 2 & $\begin{array}{l}\text { Andhra } \\
\text { Pradesh }\end{array}$ & 15.89 & 2 & Tripura & 24.83 & 2 & Bihar & 17.10 \\
\hline 3 & $\begin{array}{l}\text { Himachal } \\
\text { Pradesh }\end{array}$ & 15.53 & 3 & Mizoram & 24.59 & 3 & Meghalaya & 17.04 \\
\hline 4 & Uttarakhand & 15.11 & 4 & Assam & 24.52 & 4 & Gujarat & 15.99 \\
\hline 5 & Haryana & 15.11 & 5 & West Bengal & 23.39 & 5 & Chandigarh & 15.84 \\
\hline 6 & $\begin{array}{l}\text { Jammu \& } \\
\text { Kashmir }\end{array}$ & 12.92 & 6 & Maharashtra & 21.74 & 6 & Maharashtra & 15.76 \\
\hline 7 & Manipur & 12.46 & 7 & $\begin{array}{l}\text { Jammu \& } \\
\text { Kashmir }\end{array}$ & 20.96 & 7 & Goa & 15.19 \\
\hline 8 & Punjab & 11.62 & 8 & Goa & 19.96 & 8 & Sikkim & 14.12 \\
\hline 9 & Chandigarh & 11.58 & 9 & Chandigarh & 19.51 & 9 & Karnataka & 13.03 \\
\hline 10 & Tamil Nadu & 11.20 & 10 & Manipur & 17.91 & 10 & $\begin{array}{l}\text { Andhra } \\
\text { Pradesh }\end{array}$ & 10.94 \\
\hline
\end{tabular}

Source: Compiled by the Authors used Census data.

Punjab (36.24 per cent). Except the states listed as bottom ten in sequence in Table 8 , the rest come under middle states category with regard to secondary education. As is evident from the discussion above, over a period of time, percentage of literates (both male and female) among the disabled population has increased during the decade 2001-2011. Also, the percent of disabled both male and female having attained higher levels of education (secondary/graduate and above) has increased over time. The Top ten states with the highest educational level of education (Graduate and above) in percentage term are Chandigarh (20.53 per cent), Manipur (12.76 per cent), Andhra Pradesh (12.25 per cent), Karnataka (11.31 per cent), Uttarakhand (11.20 per cent), Tamil Nadu (10.93 per cent), Maharashtra (10.90 per cent), Goa (10.45 per cent), Haryana (10.25 per cent) and Uttar Pradesh ( 9.76 per cent). Bottom ten states in this regard are listed in Table 8. Nine out of the ten states in the bottom-ten category are from the north-east, and the remaining one, i.e. Kerala is from the south. The rest of the states are 


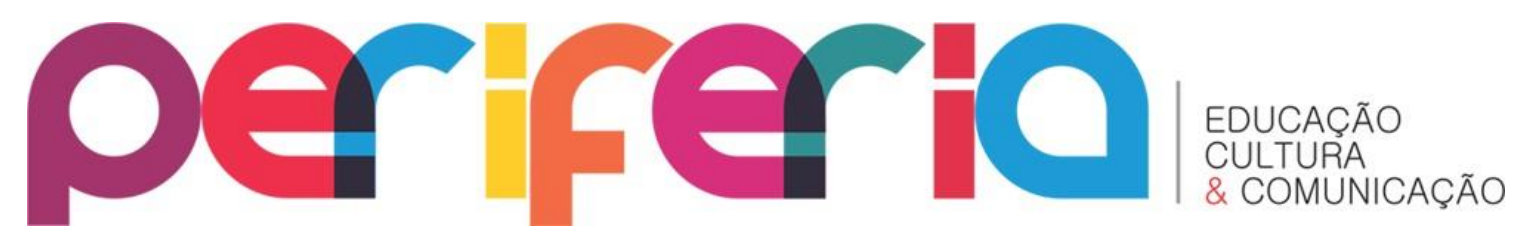

considered as middle category level states with regard to attainment of educational level of Graduation and above.

\section{SUMMARY AND CONCLUSION}

Currently India has about 2.1 per cent disabled persons in the total population. An important finding of this study is that bigger states like Uttar Pradesh, Maharashtra, Andhra Pradesh, Bihar, West Bengal, Madhya Pradesh, and Tamil Nadu have higher incidence of disability and account for a large proportion of disabled population in the country. In the decade 2001-2011, decline in the number of disabled was slightly higher in urban India than in rural India. According to recent estimates, male disability is more than female disability in India. However, in absolute numbers, male disability has declined over time though such decline has been slower among males compared to female disability. Hence, currently the proportion o disabled is higher among males than females. This alarming trend needs greater academic attention if the country wants to bring down disability among males in India in the days to come. Another positive finding of this study is that the decline in disability among both males and females is higher in rural India than in urban.

In 2001, female disability was higher than male disability in the southern states of Andhra Pradesh, Karnataka, and Tamil Nadu and also in the states of Odisha and Rajasthan. However, female disability between 2001 and 2011 increased in the states of West Bengal, Madhya Pradesh, and Odisha. Interestingly, the state of Karnataka has been an exception to the general trend of increasing disability among both genders as per 2011 census. Further, between 2001 and 2011, the incidence of disability in rural areas across the top ten states increased in percentage terms, higher incidence being in the states of West Bengal, Tamil Nadu, Rajasthan, and Madhya Pradesh, while the remaining states like Uttar Pradesh, Bihar, Andhra Pradesh and Odisha experienced considerable decline.

Between 2001 and 2011, increased disability in percentage terms was high in the state of West Bengal, Tamil Nadu, Rajasthan, and Madhya Pradesh, 


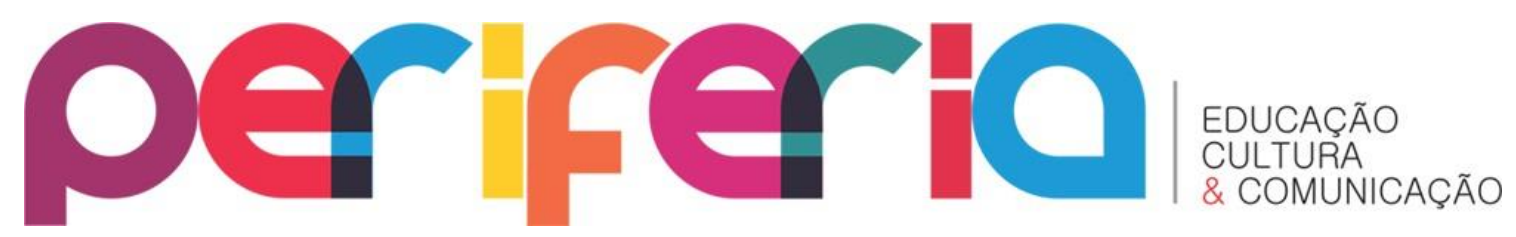

Uttar Pradesh, Bihar, Andhra Pradesh and Odisha. Similarly these states also had the dubious distinction of having higher incidence of rural disability of both males and females. In the decade 2001 and 2011, the western states of Goa and Maharashtra, the north- eastern states of Manipur, Jharkhand and the state of Andhra Pradesh witnessed fast growth of population both in absolute and percentage terms.

It has evident that with regard to educational status among disabled to be noting that during the last two decades not only the educational status of the disabled population has improved, but the percentage of literates among both male and female disabled population has also increased; and their status in higher educational levels has also improved consequently. Gender-wise, the decade 2001-2011 witnessed attainment of increased higher educational level by disabled females compared to disabled males, the increase being 4.3 per cent and 3.1 per cent respectively for matric/secondary, Graduate and above as compared to disabled males with 3.4 per cent and 2.4 per cent increase respectively. The level of primary, below middle, secondary, Graduation and above attainment by female disabled is the highest in the states of Mizoram, Odisha, Jammu \& Kashmir and the developed state of Punjab in that order.

In India, the Central Ministry of Social Justice and Empowerment is the nodal agency of that promoted services for the people with disabilities through its various schemes such as Regional Rehabilitation Training Centre (RRTC) till 1985. National Information Centre on Disability \& Rehabilitation (NICDR), came up in 1987, and subsequently, entities like the National Council For Handicapped Welfare, National Handicapped Finance \& Development Corporation etc. emerged. The main aim of the Ministry was to promote services for disabled persons through government and non-government organizations, so that disabled are encouraged to become functionally independent and productive members of the nation through opportunities of education, vocational training, medical rehabilitation, and socio-economic rehabilitation. 


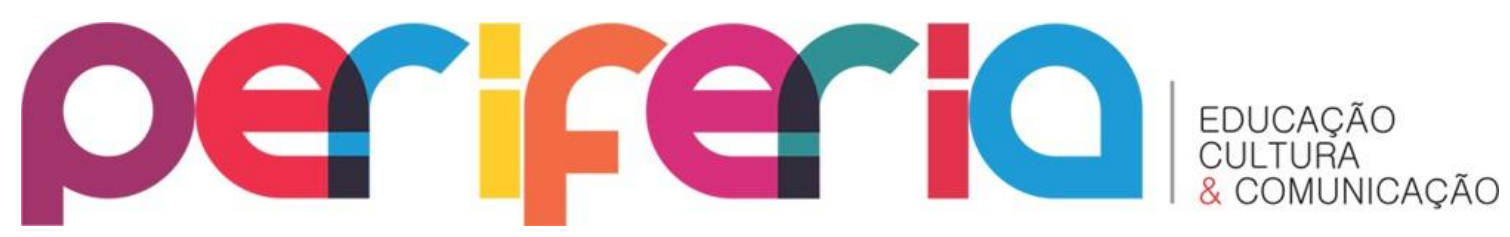

Considering above, the study strongly suggest that the above schemes and plans should be further fine-tuned to work towards the betterment of disabled population in their social, educational and economic empowerment in general, and social security in particular. As is apparent, the poverty is the main cause of disability which is a vicious circle that aggravates incidence of disability in India. Given the existing frame work and strategies, the concern of the department should be to take note the findings of the present study and chalk out programmes for the overall betterment of the country's disabled population, which account for about 2 percent of the country's total population.

\section{REFERENCES}

CHAUDHURI, Leni. Disability in India: Issues and Concerns, Ess Conference Paper, May, 2006.

GROCE, Nora; KEMBHAVI, Gayatri; WIRZ, Shelia; LANG, Raymond; TRANI, JeanFrancois; KETT, Maria. Poverty and disability - a critical review of the literature in Low and Middle-Income Countries. Leonard Cheshire Disability and Inclusive Development Centre. September 2011.

GSDRC - Applied Knowledge Services - http://www.gsdrc.org/topicguides/disability-inclusion/the-situation-of-people-with-disabilities/povertyand-disability/\#groce-et-al-2011, Disability inclusion-Topic guide, Nov, 2015

MACHA, Hidegard; FATHRENWALD, Claudia and BAUER, Quirin J (editors) Indian Women in 21st century: Emerging Issues and Challenges with reference to Educational Leadership, in edited volume, Gender and Education-Towards New Strategies. Druck and Verlag e-publishers, GMBH, Berlin, Germany (2011) NATIONAL UNIVERSITY OF EDUCATIONAL PLANNING \& ADMINISTRATION. The National Report "Status of Education in India "submitted to Department of Higher Education, Ministry of Human Resource Development. Government of India, New Delhi, 2008.

REGISTRAR GENERAL OF INDIA, Data on disabled population 2001 and 2011, Ministry of Home Affairs, Government of India. 2016.

SEN, Amarthya; WOLFENSOHN, James D. Helping Disabled People out of the Shadows, New Perspective Quarterly, v.31, n.2, Spring 2014. 


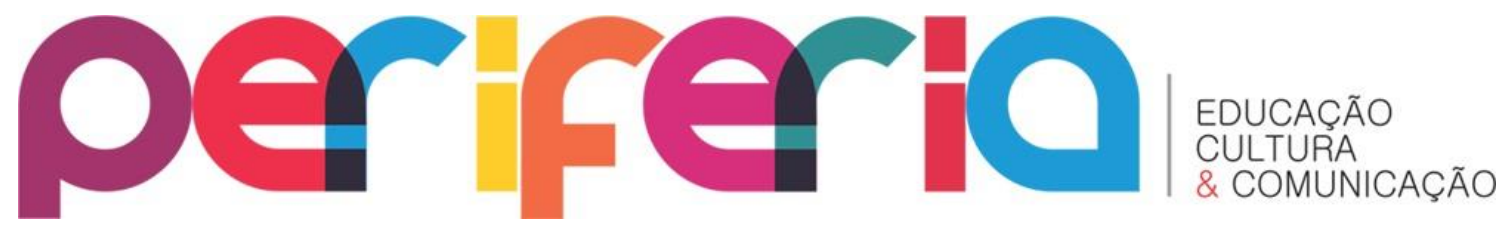

WOMEN HEALTH, EDUCATION AND EMPOWERMENT: India's Status and Challenges'. International Journal of Development and Social Research, Issues. Xavier Institute of Management, Bhubaneswar. No. 1 and Vol. No.1. 2010. 